H. Peterson, Ed., (AGU Mongr. 55, American Geophysical Union, Washington, DC, 1989), pp. 165236.

29. C. J. Yapp and S. Epstein, Earth Planet. Sci. Lett. 34, 333 (1977)

30. Altitude-normalized limber pine $\delta^{13} \mathrm{C}$ values were averaged for each time period and 1.5 per mil was subtracted to account for observed holocellulose to whole-tissue isotopic differences [S. W. Leavitt and A. Long, Nature 298, 742 (1982); Chem. Geol. 87
59 (1991)]. Discrimination $(\Delta)$ and $C_{i} / C_{a}$ values were calculated with both sets of $\delta^{13} C_{\text {air }}$ and these results were averaged. Average atmospheric $\mathrm{CO}_{2}$ concentrations were taken from (3)

31. We thank K. L. Cole, R. S. Thompson, W. G Spaulding, P. E. Wigand, J. I. Mead, and L. Agenbroad for limber pine macrofossils; A. Neftel for $\mathrm{CO}_{2}$ values from the Byrd ice core; $M$. Schiffer and D. Killick for access to their reflecting light microscope; D. Bentley for scanning electron microscopy images; A. J. T. Jull and D. Donahue for AMS dates; A. Long for discussion and technical support; S. Danzer and T. Newberry for sample preparation; and J. Ehleringer, R. Sage H. B. Johnson, and I. Winograd for critical reading of the manuscript. Support provided by the state of Arizona and the U.S. Geological Survey's Global Change Program

1 November 1993; accepted 7 February 1994

\title{
Quantifying Global Warming from the Retreat of Glaciers
}

\section{Johannes Oerlemans}

Records of glacier fluctuations compiled by the World Glacier Monitoring Service can be used to derive an independent estimate of global warming during the last 100 years. Records of different glaciers are made comparable by a two-step scaling procedure: one allowing for differences in glacier geometry, the other for differences in climate sensitivity. The retreat of glaciers during the last 100 years appears to be coherent over the globe. On the basis of modeling of the climate sensitivity of glaciers, the observed glacier retreat can be explained by a linear warming trend of 0.66 kelvin per century.

As suggested by many historic records, valley glaciers are sensitive indicators of climatic change (1-5). This large sensitivity is a consequence of the typical properties of a melting ice or snow surface. Because the surface temperature is fixed during melting, an increasing flow of energy to the surface, either by radiation or air motion, is used entirely for additional melting. In contrast, a normal surface would raise its temperature and radiate more energy upward to restore the balance.

The monitoring of glacier mass balance (annual mass gain or loss at the surface) is the best way to infer climatic change with glaciers. Although such measurements are being made on selected glaciers, the available records are short $(<45$ years, $<30$ years in most cases). Records of glacier length are much longer, some beginning around A.D. 1600, and can be used to provide information on climate variability. Many glaciers have retreated over the last 100 or 150 years (Fig. 1). Current understanding of glacier dynamics permits a quantification of the climate change needed to explain this retreat (in the same spirit as the use of tree-ring data or oxygen isotope values from ice cores). Although very discontinuous in time, the data points are reliable, especially with regard to the maximum glacier extent because the trimlines and moraine systems left behind can be studied. However, to provide information on global climate, the records must be scaled and considered together.

The climatic interpretation of a change

Institute for Marine and Atmospheric Research, Utrecht University, Princetonplein 5, 3584 CC Utrecht, Netherlands. in glacier length is hampered because response times are different for different glaciers $(5,6)$. For most valley glaciers, the response time is 10 to 50 years. When studies are in a significantly longer time scale, $>75$ years, a workable assumption is that the long-term change in glacier length largely reflects the dependence of the equilibrium glacier state on climate. More formally, climate and glacier fluctuations over a specific period can be viewed as composed of a linear trend on which smaller scale fluctuations are imposed. In this report, I try to find this linear component, thereby assuming that glacier extent is in balance with climate. This assumption will be more accurate when the period considered is longer. Here I consider the period 1850 to 1990 (but the average length of the records used is only 94 years).

In total, I used records from 48 glaciers in the analysis, considering data from only 1850 onward (Table 1) (7-11). I calculated linear trends of change in glacier length for all glaciers, irrespective of the start or end of the record. All glacier fronts appeared to have retreated; the mean rates were between 86 and $1.3 \mathrm{~m} /$ year. Next I used a two-step scaling procedure to make results from different glaciers comparable. The first step allows for the notion that glaciers with

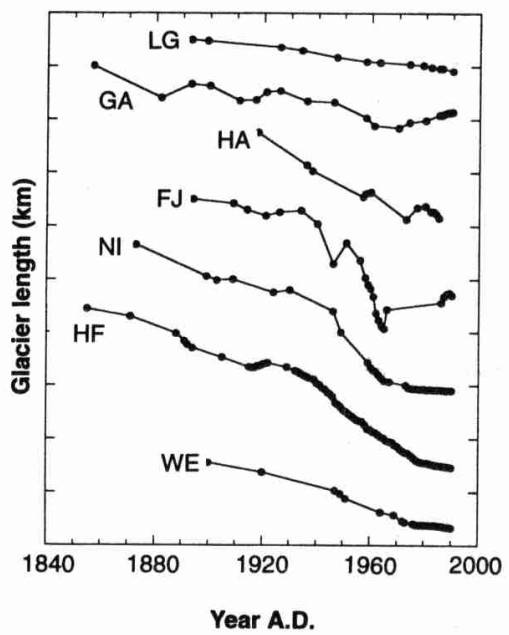

Fig. 1. Examples of fluctuations in glacier length. Data were compiled by the World Glacier Monitoring Service (Zürich), with some additions (7). Each dot represents an observation. Glaciers shown are Lewis Glacier (LG. Kenya), Glacier d'Argentière (GA, France), Hansbreen (HA, Spitsbergen), Franz Joseph Glacier (FJ, New Zealand), Nigardsbreen (NI, Norway), Hintereisferner (HF, Austria), and Wedgemount Glacier (WE, Canada). In these records, retreat has stopped or slowed as a response to the decrease in global temperature from 1950 to $1975(21,22)$. This observation suggests an effective glacier response time of about 25 years.

Table 1. Summary of the results for different regions. In total, data from 48 glaciers were used (11).

\begin{tabular}{lclcrr}
\hline \multicolumn{1}{c}{ Region } & $\begin{array}{c}\text { Number } \\
\text { of } \\
\text { glaciers }\end{array}$ & $\begin{array}{c}\text { Data } \\
\text { source } \\
\text { (refer- } \\
\text { ence) }\end{array}$ & Period & $\begin{array}{c}\text { Mean } \\
\text { trend } \\
\text { (m/year) }\end{array}$ & $\begin{array}{c}\text { Scaled } \\
\text { mean } \\
\text { trend } \\
\text { (m/year) }\end{array}$ \\
\hline Rocky Mountains & 24 & $(7)$ & 1890 to 1974 & -15.2 & -13.7 \\
Spitsbergen & 3 & $(7)$ & 1906 to 1990 & -51.7 & -14.9 \\
Iceland & 1 & $(8)$ & 1850 to 1965 & -12.2 & -6.3 \\
Norway & 2 & $(7,9)$ & 1850 to 1990 & -28.7 & -12.1 \\
Alps & 4 & $(7)$ & 1850 to 1988 & -15.6 & -9.3 \\
Central Asia & 9 & $(7)$ & 1874 to 1980 & -9.9 & -13.3 \\
Irian Jaya & 2 & $(7)$ & 1936 to 1990 & -25.9 & -7.1 \\
Kenya & 2 & $(7,10)$ & 1893 to 1987 & -4.8 & -6.7 \\
New Zealand & 1 & $(7)$ & 1894 to 1990 & -25.9 & -13.9 \\
\hline
\end{tabular}


Table 2. Calculated mean trends in glacier length $(t)$, scaled with surface slope $\left(t^{\star}\right)$ and with surface slope and climate sensitivity $\left(t^{\star \star}\right)$.

\begin{tabular}{lccc}
\hline $\begin{array}{c}\text { Param- } \\
\text { eter }\end{array}$ & $\begin{array}{c}\text { Mean } \\
\text { (m/year) }\end{array}$ & $\begin{array}{c}\text { SD } \\
\text { (m/year) }\end{array}$ & $\begin{array}{c}\text { Signal-to- } \\
\text { noise ratio }\end{array}$ \\
\hline$t$ & -17.2 & 14.1 & 1.22 \\
$t^{*}$ & -13.8 & 8.3 & 1.66 \\
$t^{* *}$ & -13.1 & 6.8 & 1.93 \\
\hline
\end{tabular}

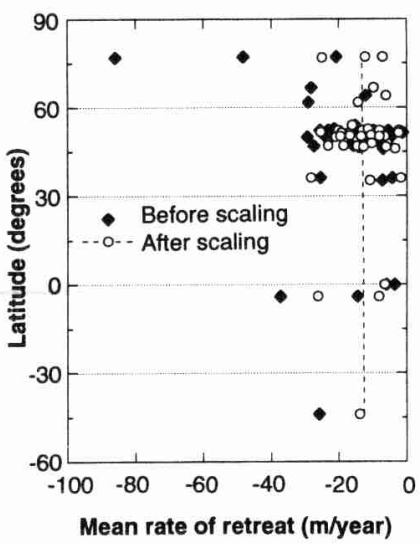

Fig. 2. Calculated linear trends in glacier length for the entire sample of 48 glaciers, plotted as a function of latitude. Note the reduction of variance by the scaling procedure. The effect is most pronounced for the glaciers on Spitsbergen because they have a very small slope. The dashed line shows a linear fit of the scaled trends with latitude. Apparently, there is no significant dependence of $t^{\star *}$ on latitude.

a smaller surface slope are more sensitive to climate change than are steep glaciers, at least with regard to their length. This relation has been demonstrated by numerical modeling and by simple arguments (12, 13). The first scaling is

$$
t^{*}=\frac{t \times s}{\bar{s}}
$$

where $t$ is the linear trend of glacier length, $t^{*}$ is the trend corrected for surface slope $s$, and $s$ is the mean slope averaged over all glaciers in the sample. Characteristic values of $s$ were estimated from the maximum and minimum glacier elevation and glacier length $(7,8)$.

The second scaling takes care of the differences in climate sensitivity among the glaciers. Considering only annual mean air temperature, I define climate sensitivity $\mathrm{C}$ as the change of glacier mass balance (averaged over the entire glacier surface) to a $1 \mathrm{~K}$ temperature change. Modeling of the mass balance of glaciers has shown that $\mathrm{C}$ mainly depends on the amount of precipitation falling on a glacier according to

$$
\mathrm{C}=-0.51-0.66 \log (P)
$$

(for $P \geq 0.22 \mathrm{~m} /$ year) where $P$ is the annual precipitation (14). Values of $P$ were estimated from climatological tables and maps

Table 3. The dependence of glacier length $L$ on annual mean temperature $T$, as modeled by variou: workers. For the results in the present analysis to be used, $d L / d T$ has to be multiplied by the appropriate scaling factor $(s / C)(\overline{\mathrm{C}} / \overline{\mathrm{s}})$. The mean for $(d L / d T)^{\star \star}$, the change of scaled glacier lengt with temperature, is $1.98 \mathrm{~km}$ per degree.

\begin{tabular}{llcc}
\hline \multicolumn{1}{c}{$\begin{array}{c}\text { Location } \\
\text { (reference) }\end{array}$} & $\begin{array}{c}d L / d T \\
(\mathrm{~km} / \mathrm{K})\end{array}$ & $\begin{array}{c}\text { Scaling } \\
\text { factor }\end{array}$ & $\begin{array}{c}(\mathrm{dL} / \mathrm{dT})^{*-1} \\
(\mathrm{~km} / \mathrm{K})\end{array}$ \\
\hline Hintereisferner (16) & 4.26 & 0.52 & 2.20 \\
Nigardsbreen (17) & 4.50 & 0.48 & 2.16 \\
Rhonegletscher (18) & 3.98 & 0.48 & 1.91 \\
Glacier d'Argentière (19) & 4.23 & 0.48 & 2.02 \\
Lewis Glacier (20) & 1.5 & 1.09 & 1.63 \\
\hline
\end{tabular}
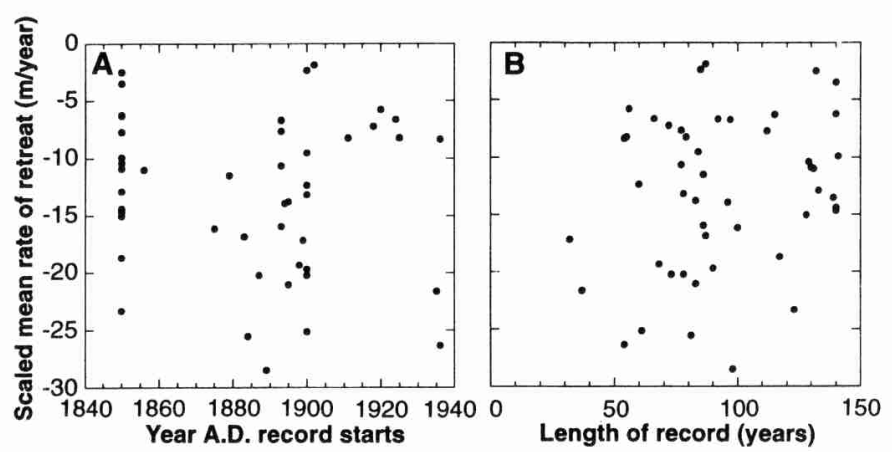

(15). For the present sample, this estimation implies that $C$ ranges from $0.9 \mathrm{~m}$ of water equivalent per degree in air temperature for the glaciers in moist climates to $0.23 \mathrm{~m}$ of water equivalent per degree in air temperature for the dryer glaciers. So the scaled linear trend, $t^{* *}$, is now

$$
t^{* *}=\frac{t^{*} \times \overline{\mathrm{C}}}{\mathrm{C}}=\frac{t \times s}{\mathrm{C}} \overline{\overline{\mathrm{C}}}
$$

A comparison of values of $t$ and $t^{* *}$ obtained in this way reveals that the scatter of trends is considerably reduced by the scaling procedure (Fig. 2 and Table 2). For global mean values, the signal-to-noise ratio, defined as the mean trend divided by the standard deviation, appears to increase from 1.22 for the nonscaled values to 1.93 for the scaled values. This increase shows that the scaling makes sense.

To relate the scaled mean glacier retreat to temperature change, glacier dynamics must be considered. Values of $d L / d T$, that is, the sensitivity of glacier length $L$ to temperature $T$, can be obtained from studies with numerical ice flow models. Several of these have been carried out in recent years (Table 3) $(16-20)$. The scaled mean value found in this way yields a $2.0-\mathrm{km}$ change in glacier length for a temperature change of $1 \mathrm{~K}$. The average starting and ending dates of all records are 1884 and 1978. Over this 94-year period, the scaled mean glacier retreat is $1.23 \mathrm{~km}$, indicating a $0.62 \pm 0.09 \mathrm{~K}$ warming over this period, corresponding to $0.66 \pm 0.10 \mathrm{~K}$ per 100 years [the uncertainty is based on a $30 \%$ error in the individual estimates of slope and climate sensitivity and on the assumption that the regions (Table 1), but not the glaciers within a region, have independent errors].

The total error may be twice as large (on the order of $0.2 \mathrm{~K}$ ). Factors other than temperature affect the size of glaciers, nota bly precipitation and cloud cover. For the largest glaciers in the sample, the response times may be larger than those desired for this study. The inhomogeneity of the dat adds to this deviation. Some of the record begin in 1850, and others begin in 1925 Also, most of the records are in the mid latitudes of the Northern Hemisphere. therefore used several subsamples to evalu ate the sensitivity of the results to thes effects, that is, by averaging by region first. The assignment of a smaller weight to th cluster of records from the Northern Hems. sphere mid-latitudes has no effect. Sam pling in dependence of the start of the record or the length of the record also does not change the result (Fig. 3).

For comparison, the observed temperature trends from the series of Jones (21) are $0.41 \mathrm{~K}$ per century (mean for the period 1861 to 1991; a value of $0.42 \mathrm{~K}$ per century is foun for the period 1884 to 1978 ). The data put lished by Hansen and Lebedeff (22) yield 0.53 $\mathrm{K}$ per century (mean for the period $1881 \mathrm{t}$ ) 1987). These values are slightly less than the independent estimate of $0.66 \pm 0.2 \mathrm{~K}$ foun 1 from the analysis of glacier retreat.

\section{REFERENCES AND NOTES}

1. J. F. Nye, Proc R. Soc. London 256, 559 (1960)

2. H. Hoinkes and R. Steinacker, Riv. Ital. Geofis. Sci. Affini 1, 97 (1975). 
3. M. Kuhn, Int. Assoc. Hydrol. Sci. Publ. 131 (1981) p. 3.

4. J. Oerlemans, Nature 320, 430 (1986).

5. W. F. Budd and D. Jenssen, Int. Assoc. Hydrol. Sci. Publ. 131 (1975), p. 257

6. M. Kuhn, Z. Gletscherkd Glazialgeol. 21, 409 (1985)

7. International Association of Hydrological Sciences, Fluctuations of Glaciers (Unesco, Paris, 1967, 1973 1977. 1985, 1988), vols. 1-5. Apart from data on glacier length and mass balance, the World Glacier Inventory contains information on the following characteristics of glaciers on which studies have been carried out: geographical position; exposure; maximum, median, and minimum elevation; area; length.

8. H. Björnsson, Jokull 29, 74 (1979). The data used are the mean change for nine outlet glaciers from the Vatnajökull. A mean slope was estimated from maps of $\mathrm{H}$. Björnsson [Hydrology of lce Caps in Volcanic Regions (University of Iceland, Reykjavik, 1988)].

9. J. Bogen, B. Wold, G. Østrem, in Glacier Fluctuations and Climatic Change, J. Oerlemans, Ed. (Kluwer, Dordrecht, Netherlands, 1989), pp. 109-128.

10. S. Hastenrath, The Glaciers of Equatorial East Africa (Kluwer, Dordrecht, Netherlands, 1984), chap. 6.

11. The glaciers used in the analysis are Ape, Athabasca, Asulkan, Clendenning, Drummond, Fleur d. Neiges, Fyles, Griffin, Havoc, Illecillewaet, New Moon, Noeick, Peyto, Purgatory, Saskatchewan Sentinel, Staircase, Surf, Terrific, Tsoloss, Victoria Wedgemount (Canada); Eel, White (United States); Samarin, Hans, Paierl (Spitsbergen); Vatnajökull (Iceland); Engabreen, Nigardsbreen (Norway); Rhone, Untere Grindelwald (Switzerland); Hin- tereis (Austria); Argentière (France); Bolshoy AbylOyuk, Geblera, Bolshoy Maashey, Maliy Aktru, Rodzevicha, Sapozhnikova (Russia/Kazakhstan) Chungpar-Tash., Chogo Lungma, Minapin (Pakistan); Cartensz, Meren (Irian Jaya); Lewis, Tyndal (Kenya); Franz Josef (New Zealand).

12. D. J. Furbish and J. T. Andrews, J. Glaciol. 30 199 (1984)

13. J. Oerlemans, in (9), pp. 353-371

14. J. Oerlemans and J.P. F. Fortuin, Science 258 115 (1992)

15. M. J. Müller, Handbuch ausgewählter Klimastationen der Erde (Universität Trier, Trier, Germany, 1987); additional data from various climate atlases.

16. W. Greuell, J. Glaciol. 38, 233 (1992)

17. J. Oerlemans, ibid., p. 223.

18. Ph. Huybrechts, P. De Nooze, H. Decleir, in (9), pp. 373-389

19. A. Stroeven, R. Van De Wal, J. Oerlemans, in (9), pp. $391-405$

20. P. D. Kruss, Z. Gletscherkd Glazialgeol. 19, 43 (1984).

21. P. D. Jones, Clim. Monit. 18, 80 (1989)

22. J. Hansen and S. Lebedeff, J. Geophys. Res. 92 13345 (1987)

23. I thank W. Greuell for useful comments. Part of this work was carried out at the International Institute for Applied Systems Analysis in Laxenburg. Supported by the Netherlands Organization for Scientific Research, the Dutch National Research Programme on Global Air Pollution and Climate Change (contract 276/91-NOP), and the Commission of the European Communities (contract EV5V-CT91-0051).

8 November 1993; accepted 2 February 1994

\title{
Morphological Bifurcations Involving Reaction-Diffusion Processes During Microtubule Formation
}

\author{
James Tabony
}

Nonlinear chemically dissipative mechanisms have been proposed as providing a possible underlying process for some aspects of biological self-organization, pattern formation, and morphogenesis. Nonlinearities during the formation of microtubular solutions result in a chemical instability and bifurcation between pathways leading to macroscopically selforganized states of different morphology. The self-organizing process, which contains reactive and diffusive contributions, involves chemical waves and differences in microtubule concentration in the sample. Patterns of similar appearance are observed at different distance scales. This behavior is in agreement with theories of chemically dissipative systems.

\begin{abstract}
Spontaneous macroscopic self-organization can occur when a system is moved from a linear equilibrium state to a nonlinear outof-equilibrium state. After an instability in the initial state, the system bifurcates into one of two possible new configurations (14). Fields, which are normally too weak to effect equilibrium structures, can play a decisive role in determining the morphology of the final state. Turing (5), and later Prigogine and co-workers $(3,4,6)$, proposed and developed the idea that chemical

Laboratoire de Résonance Magnétique en Biologie e Médecine, Département de Biologie Moléculaire et Structurale, Centre d'Etudes Nucléaire de Grenoble,

$85 \mathrm{X}, 38041$ Grenoble, Cedex, France.
\end{abstract}

biochemical system of microtubule assembly behaves in the manner outlined above.

Microtubules (11) play a controlling role in organizing the cytoskeleton. These are tubular molecular assemblies, $280 \AA$ in diameter and several micrometers in length, comprised of the protein tubulin and that can be formed by warming $\left(4^{\circ}\right.$ to $\left.35^{\circ} \mathrm{C}\right)$ a solution containing purified tubulin and the nucleotide, guanosine triphosphate (GTP). The tubulin spontaneously assembles into microtubules, chemical reactions occur, and GTP is hydrolyzed to guanosine diphosphate (GDP). This reaction continues after microtubule formation is initially completed, by the addition and loss of tubulin at the opposing ends of the microtubules. Frequently, a GTP regenerating system (12) is included in which GDP, as produced, is rephosphorylated to GTP by a kinase enzyme in the presence of the appropriate organic phosphate. The concentration of GTP remains constant, and the net reaction is a consumption of the organic phosphate. The assembly process can show nonlinear kinetics (13), and the system is hence capable of manifesting various complex nonlinear phenomena. Some microtubular solutions show spontaneous macroscopic space ordering (14-18), a phenomenon that has been attributed to chemically dissipative mechanisms $(17,18)$. After assembly in optical cells, stationary periodic horizontal stripes of about 0.5 to $1 \mathrm{~mm}$ separation progressively develop in the sample. In each band the microtubules are highly oriented at either an acute or obtuse angle, but adjacent stripes differ in having opposing orientations (17). Striped morphologies occur when the microtubules are prepared in upright sample containers, but a different pattern arises when they are prepared in horizontal cells (19). This behavior is attributed to the determining role of the direction of the gravitational field (19).

According to theories of chemically dissipative systems, the presence of a weak field at the moment of a chemical instability determines whether a system bifurcates along one morphological pathway or another. To establish at what moment the sample morphology depends on the orientation of the cell with respect to gravity, I performed the following experiment. Twenty samples of phosphocellulose-purified tubulin $(10 \mathrm{mg} / \mathrm{ml})(20)$, together with GTP and a GTP regenerating system $(17)$, at $4^{\circ} \mathrm{C}$, were placed in optical cells $4 \mathrm{~cm}$ by $1 \mathrm{~cm}$ by $0.1 \mathrm{~cm}$. Microtubule formation was initiated by placement of the cells upright in a thermostatted room at $35^{\circ} \mathrm{C}$. At 1-min intervals consecutive cells were layed flat, and the samples were examined about 12 hours later through cross polars with a wavelength compensater (Fig. 1A). When observed in this way (21), acute and obtuse microtubule orientations produce blue and yellow interference colors, respectively. After 